\title{
Epidemiology of hip fractures in Ecuador
}

\author{
Carlos H. Orces ${ }^{1}$
}

Suggested citation $\quad$ Orces CH. Epidemiology of hip fractures in Ecuador. Rev Panam Salud Publica. 2009;25(5):438-42.

ABSTRACT Objectives. To report the age-, sex-, and type-specific hip fracture incidence rates in Ecuador. A secondary objective was to examine hip fracture geographic variations in Latin America.

Methods. The Anuario de Egresos Hospitalarios was analyzed to determine the number of persons aged 50 years or older hospitalized with a principal diagnosis of hip fracture (ICD-10 S72) in 2005. Census estimates of the population were used as the denominator to calculate hip fracture incidence rates per 100000 inhabitants. Age-adjusted rates were calculated by the direct method using the 2000 U.S. population as the standard to examine hip fracture geographic variations.

Results. A total of 1005 persons were hospitalized with a diagnosis of hip fracture (664 women and 341 men) during the study period. The crude annual incidence rate of hip fractures was 49.5 per 100000 (34.8 per 100000 men and 63.2 per 100000 women). In general, the number and incidence of hip fractures increased exponentially with age in both sexes. However, the increase was more relevant in women. Age-adjusted rates in Latin America ranged from a low of 15.1 per 100000 in women and 6.7 per 100000 in men for Sobral, Brazil, to a high of 499.0 per 100000 in women for La Plata, Argentina.

Conclusions. The results of this study indicate a low incidence of hip fractures in Ecuador and geographic differences of hip fracture rates in Latin America. Because the population of Ecuador is aging, this study provides valuable information for public health authorities to start planning and implementing prevention strategies aimed at reducing the burden of hip fractures in the near future.

Key words Hip fractures, osteoporosis, Ecuador.

Hip fractures represent the most serious complication of osteoporosis and are associated with considerable morbidity, mortality, and health care cost (1-3). Previous studies have reported geographic

\footnotetext{
Laredo Medical Center-Medicine, 1700 East Saunders, Laredo, Texas, United States of America. Send correspondence and reprint requests to: Carlos H. Orces, MD, MPH, Laredo Medical Center-Medicine, 1700 East Saunders, Laredo 78041, TX, United States of America; telephone: (956) 7124077; e-mail: corces07@yahoo.com
}

variation in the incidence of hip fracture between and within countries $(4,5)$, with the highest rates in northern European countries, followed by Caucasians in North America and Asia, and the lowest rates in South America (5).

Cooper et al. estimated that the total number of hip fractures worldwide will increase from 1.26 million in 1990 to 2.6 million by 2025 and to 4.5 million by 2050 (2). Because life expectancy is increasing in most countries, the proportion of older adults in Latin America will increase from $5.8 \%$ in 2005 to $17 \%$ in 2050 (6). This demographic shift over the next 50 years will result in a significant number of hip fractures occurring in the region. In fact, it is expected that $75 \%$ of the burden from hip fractures will come from developing countries and the remaining 25\% will come from the developed world, where a stabilization or decrease in hip fracture rates has been documented $(7,8)$. Despite these facts, knowledge of the epidemiology of osteoporotic fractures in most countries from 
Latin America remains limited except for a few industrialized nations (9). Therefore, the main objective of this study was to report the age-, sex-, and type-specific hip fracture incidence rates in Ecuador in 2005. A secondary objective was to examine hip fracture geographic variations in Latin America.

\section{MATERIALS AND METHODS}

Ecuador is located in the northwestern part of South America, with a territory of 256370 square kilometers. In 2005, the Instituto Nacional de Estadística y Censos de Ecuador (INEC) estimated 13215089 inhabitants (48.2\% men and $51.8 \%$ women). Sixty-one percent of the population lived in urban areas, with $39 \%$ in rural areas (10).

Ecuador's climate varies from one region to another, due to differences in altitude, longitude, and latitude. Seasonal differences are reflected mainly in variations in rainfall. The Pacific Coast varies during the wet season from December to May and the temperatures range between $23^{\circ} \mathrm{C}$ and $26^{\circ} \mathrm{C}$. The climate in the Andes Mountains is cold and rainy from November to April and the temperatures range from $13^{\circ} \mathrm{C}$ to $18^{\circ} \mathrm{C}$. In the Amazon, the temperature ranges between $23^{\circ} \mathrm{C}$ and $36^{\circ} \mathrm{C}$ and the climate is rainy and humid most of the year (11).

Approximately $49 \%$ of the population lives along the Pacific Coast, $44.5 \%$ in the Andes Mountains, $4.7 \%$ in the Amazon region, $0.1 \%$ on the islands, and $0.7 \%$ in areas not delimited. According to the 2000 Household Survey, $72 \%$ of the population older than 15 years of age considered appropriate the mestizo (mixed Indian and white) designation; 15\% defined themselves as white, $6 \%$ as Indian, $4 \%$ as black, and $2 \%$ as mulatto (mixed black and white) (12).

The Anuario de Egresos Hospitalarios is part of the national surveillance system conducted annually by the INEC. It covers discharges from private and public hospitals in Ecuador. Data abstracted from hospital records contain items relating to demographic and administrative information, discharge status, and principal discharge diagnosis (13).

Diagnoses are coded according to the International Classification of Diseases, 10th revision, clinical modification (ICD10-CM) (14). The data selected for this study consisted of individuals aged 50 years or older hospitalized with a princi- pal diagnosis of hip fracture (ICD-10 S72) from 1 January to 31 December 2005.

The age-, sex-, and type-specific incidence rates were calculated for age groups 50-59, 60-69, 70-79, and 80 years or older. Estimates of the Ecuadorian population by age and sex were used as the denominator to calculate incidence rates per 100000 population (10). Ageadjusted rates were calculated by the direct method using the 2000 U.S. population aged 50 years or older as the standard (15). Hip fracture incidence rates by gender for persons aged 50 years or older from selected published studies in North and South America (5, 7, 16-21) were standardized to the 2000 U.S. population to examine geographic variations. Then, standardized rate ratios were calculated to compare age-adjusted hip fracture rates from countries in Latin America using the U.S. rates as the reference. Hip fracture in the hospital mortality rate was defined as the proportion of fatal events to the total number of patients hospitalized for this condition (22). Hip fracture seasonal variation was determined with the Edward's test (23). Statistical analysis was conducted using SPSS version 11.0 (SPSS Inc, Chicago, IL) and PEPI computer software package (23). A value of $P \leq 0.05$ was considered statistically significant.

\section{RESULTS}

There were 160634 hospitalizations among persons aged 50 years or older in Ecuador during the study period. Of these hospitalizations, $1005(0.62 \%)$ hip fractures were identified. The mean age of patients was $76.4 \pm 12.7$ (standard deviation) years in men and $79.7 \pm 10.4$

\section{FIGURE 1. Age-specific hip fracture rates in Ecuador, 2005}

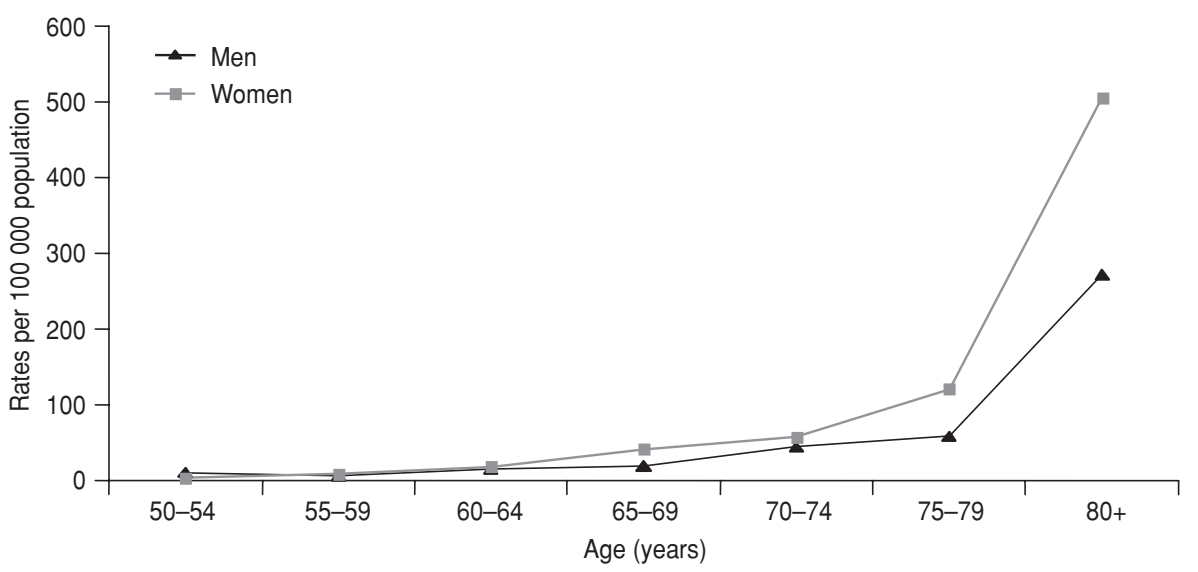

years in women. Most hip fractures occurred in the Andes Mountains (60\%), followed by the Pacific Coast (39\%) and the Amazon (1\%). The mean length of stay in public and private hospitals was $12.8 \pm$ 10.9 and $4.5 \pm 4.2$ days, respectively.

The crude annual incidence rate of hip fractures in persons aged 50 years or older was 49.5 per 100000 (34.8 per 100000 men and 63.2 per 100000 women). The age-specific hip fracture rates increased significantly for men and women in the age group 80 years or older. However, the increase was more relevant in women (Figure 1). Table 1 demonstrates an exponential increase in hip fracture rates in both sexes with increasing age, from 9.4 per 100000 (men) and 6.0 per 100000 (women) in the 50- to 59-year age group to 271.9 per 100000 (men) and 505.1 per 100000 (women) in the age group 80 years or older. Moreover, the female-tomale rate incidence ratios were more than 1 in all age groups, except the 50to 59-year age group (ratio $=0.6$ ); the highest female-to-male ratio was found among those 80 years or older (ratio = 1.9). The age-adjusted hip fracture rate was 51.7 per 100000 for men and 88.4 per 100000 for women.

The mean age of persons with cervical and trochanteric fractures was $75.1 \pm 12.7$ and $78.4 \pm 12.5$ years, respectively, in men and $79.4 \pm 10.3$ and $80.6 \pm 10.8$ years, respectively, in women. In both genders, the highest rates of these fractures were found in persons 80 years or older. The highest cervical-to-trochanteric fracture ratio among women was observed in the 70 - to 79-year age group (ratio $=3.5$ ) and among men in the 60- to 69-year age group (ratio $=2.6$ ). The overall rate ratio of cervical-to-trochanteric fractures was 
TABLE 1. Hip fracture incidence rates in Ecuador, 2005

\begin{tabular}{|c|c|c|c|c|c|c|c|}
\hline \multirow[b]{2}{*}{ Age group (years) } & \multicolumn{2}{|c|}{ Population } & \multicolumn{2}{|c|}{ Fractures } & \multicolumn{2}{|c|}{ Incidence $^{a}$} & \multirow{2}{*}{$\begin{array}{c}\text { Female- } \\
\text { to-male } \\
\text { ratio }\end{array}$} \\
\hline & Female & Male & Female & Male & Female $(95 \% \mathrm{Cl})^{\mathrm{b}}$ & Male $(95 \% \mathrm{Cl})^{\mathrm{b}}$ & \\
\hline $50-59$ & 483537 & 469686 & 29 & 44 & $6.0(4.1,8.4)$ & $9.4 \quad(6.5,11.9)$ & 0.6 \\
\hline $60-69$ & 303756 & 285503 & 88 & 50 & $29.0 \quad(23.3,35.5)$ & $17.5 \quad(13.1,22.8)$ & 1.7 \\
\hline $70-79$ & 186132 & 164404 & 157 & 83 & $84.3(71.4,97.7)$ & $50.5 \quad(40.4,62.2)$ & 1.7 \\
\hline$\geq 80$ & 77212 & 60311 & 390 & 164 & $505.1 \quad(456.9,555.9)$ & $271.9 \quad(258.0,284.2)$ & 1.9 \\
\hline Overall & 1050637 & 979904 & 664 & 341 & $63.2(58.3,67.9)$ & $34.8 \quad(31.2,38.6)$ & 1.8 \\
\hline Age-adjusted rate ${ }^{c}$ & & & & & 88.4 & 51.7 & 1.7 \\
\hline
\end{tabular}

a Rate per 100000 population.

b $95 \% \mathrm{Cl}=95 \%$ confidence interval of the odds ratio.

${ }^{c}$ Adjusted to the 2000 U.S population aged $\geq 50$ years.

2.5 in women and 1.5 in men. The in-hospital mortality rates were $4.4 \%$ and $2.9 \%$ for men and women, respectively.

Figure 2 shows the distribution of hip fractures by season in Ecuador. Overall, a 3-month peak of hip fractures was observed between July and August in the Andes Mountains (29.7\%) and on the Pacific Coast (27.8\%). However, a significant seasonal variation of hip fractures in Ecuador was not found.

Hip fracture geographic variations were noted in Latin America. Ageadjusted rates ranged from a low of 15.1 per 100000 in women and 6.7 per 100000 in men for Sobral, Brazil, to a high of 499.0 per 100000 in women for La Plata, Argentina. Standardized rate ratios, comparing the age-adjusted rates for each country with the U.S. rates are presented in Table 2. In general, Ecuador, Chile, Mexico, Brazil, and Venezuela had significantly lower rates than the United States, whereas women from populations in Argentina had rates comparable to those in the United States.

\section{DISCUSSION}

This study reports age-, sex-, and typespecific hip fracture incidence rates for men and women aged 50 years or older in Ecuador. In general, the number and incidence of hip fractures increased with age in both sexes and were higher among women. In fact, $59 \%$ and $48 \%$ of the total number of hip fractures occurred in the age group 80 years or older in women and men, respectively. Hip fracture rates were 84 times higher in women 80 years or older than in women in the 50- to 59year age group. In men, the rates were 30 times higher in the oldest age group than in the 50- to 59-year age group. Hip fracture incidence rates in Ecuador are consistent with patterns described in most

FIGURE 2. Seasonal variation of incidence of hip fracture in Ecuador, 2005

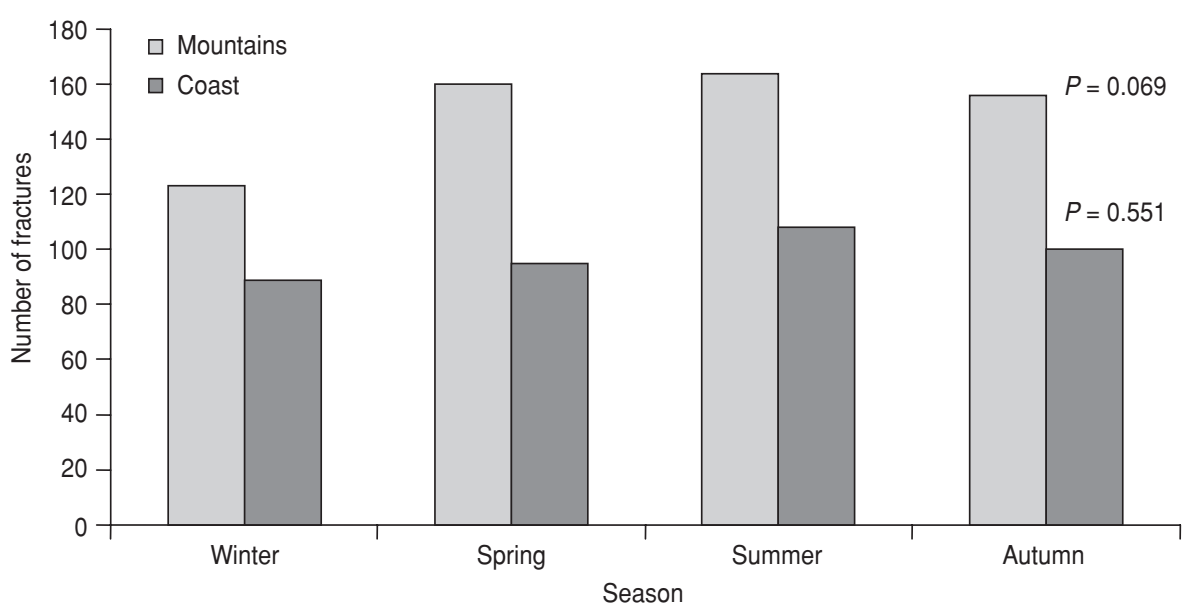

TABLE 2. Age-adjusted hip fracture rates in Latin America ${ }^{a}$

\begin{tabular}{|c|c|c|c|c|c|}
\hline \multirow[b]{2}{*}{ Country (reference) } & \multicolumn{2}{|c|}{ Women } & \multicolumn{2}{|c|}{ Men } & \multirow{2}{*}{$\begin{array}{c}\text { Year(s) of } \\
\text { study }\end{array}$} \\
\hline & Rate & Ratio & Rate & Ratio & \\
\hline \multicolumn{6}{|l|}{ United States (5) } \\
\hline Whites & 483.6 & 1 & 245.8 & 1 & 1988-1989 \\
\hline \multicolumn{6}{|l|}{ Argentina } \\
\hline Rosario (16) & 496.8 & 1.02 & 179.5 & 0.73 & 2001-2002 \\
\hline Mar del Plata (17) & 344.9 & 0.71 & 127.9 & 0.52 & $1992-1993$ \\
\hline La Plata (18) & 499.0 & 1.03 & 161.4 & 0.65 & $1989-1990$ \\
\hline \multicolumn{6}{|l|}{ Brazil } \\
\hline Fortaleza (19) & 21.3 & 0.04 & 11.7 & 0.04 & 2001-2002 \\
\hline Sobral (20) & 15.1 & 0.03 & 6.7 & 0.02 & 1996-2000 \\
\hline Chile (5) & 193.3 & 0.39 & 114.2 & 0.46 & 1985 \\
\hline Ecuador & 88.4 & 0.18 & 51.7 & 0.21 & 2005 \\
\hline Mexico (7) & 226.6 & 0.46 & 138.4 & 0.56 & 2000 \\
\hline \multicolumn{6}{|l|}{ New York, U.S. (21) } \\
\hline Whites & 456.0 & 0.94 & 228.9 & 0.93 & 1988-2002 \\
\hline Blacks & 136.6 & 0.28 & 108.8 & 0.44 & 1988-2002 \\
\hline Hispanics & 142.0 & 0.29 & 86.7 & 0.35 & 1988-2002 \\
\hline Asians & 172.4 & 0.35 & 103.3 & 0.42 & 1988-2002 \\
\hline Venezuela (5) & 85.3 & 0.17 & 51.7 & 0.21 & 1988-1989 \\
\hline
\end{tabular}

a Rate per 100000 population standardized to the 2000 U.S. population aged 50 years or older.

populations where there is a female predominance, an exponential increase with age, and an earlier age of fractures in men than in women $(20,21)$.
The increase in hip fracture incidence with aging is partly due to an age-related reduction in bone strength and an agerelated increase in risk of falling, pre- 
dominantly in women (24). A survey in Oxford, United Kingdom, reported that about 1 in 3 women aged 80-84 years had experienced a fall in the previous year; this number increased to nearly 1 in 2 women aged 85 years or older. However, only about $1 \%$ of all falls leads to a hip fracture because the amount of trauma delivered to the proximal femur depends on the orientation of the fall (20).

The overall rate ratios of cervical-totrochanteric hip fractures in Ecuador were 2.5 and 1.5 for women and men, respectively. Moreover, these fractures increased exponentially with advancing age, and the highest rates were observed in the age group 80 years or older. Persons hospitalized with trochanteric fractures were on average older than those with cervical fractures. However, cervical fracture rates were higher than trochanteric fracture rates in all age groups. Although there is no explanation for the predominance of cervical fractures reported in this study, these fractures appear to be more sensitive to the effects of nutrition, socioeconomic factors, and environmental factors (21).

It has been estimated that $8 \%$ of men and $3 \%$ of women older than 50 years of age will die during hospitalization for a hip fracture. In addition, hip-fractureassociated mortality continues to increase over the subsequent months, so that at 1 year mortality is $36 \%$ for men and $21 \%$ for women (3). The mortality risk appears to be substantially higher in men than in women, even accounting for the higher mortality rates for men in the general population (24). In this study, the hip fracture in-hospital mortality rate was $4.4 \%$ in men and $2.9 \%$ in women, which is in the $4.2 \%$ to $15 \%$ range reported in other studies (25-28).

Although most studies in Latin America have shown lower hip fracture rates than were found in the population of the United States, Canada, and Europe, these findings may be due to the selection of the population studied, differences in definition of cases, and other methodological factors (9). Moreover, the lower hip fracture rates observed in developing countries may be explained, in part, by lower life expectancy. Nevertheless, life expectancy in Ecuador increased from 58.9 years in 1970 to 71.8 years in 2005 and is expected to increase to 78.3 years in 2050. In addition, the proportion of the population 65 years or older is expected to increase from $5.1 \%$ in 2005 to $16.3 \%$ in 2050 (6). These demographic changes may markedly increase the number of hip fractures in Ecuador over the next decades.

Genetic or environmental factors may also account for the geographic variations of hip fracture rates in Latin America. Interestingly, hip fracture rates in Ecuador are similar to those in Venezuela, perhaps because of the similar racial background in those countries. However, hip fracture rates in Ecuador were significantly lower than in Argentina and the United States. Because the ethnic composition of Argentina is predominantly Caucasian, it is not surprising that the incidence of hip fractures in women from that country were comparable to those rates in Caucasian women from the United States.

Several studies have found winter peaks of hip fracture rates (29-31). However, a statistically significant seasonal variation in hip fractures was not found in Ecuador. The homogeneous annual distribution of hip fractures may be attributed to adequate sunlight in all regions of the country and to no drastic difference in ambient temperatures between winter and summer. The protective association of sunlight exposure with the risk of hip fracture has been associated with higher serum concentrations of 25-hydroxyvitamin D (32). Despite this evidence, Lips et al. recently reported that among postmenopausal women with osteoporosis even in countries with ample sunlight, vitamin D inadequacy was common. In fact, the prevalence of vitamin D deficiency $(<30$ nanograms per milliliter of blood) among postmenopausal women in Mexico, Brazil, and Chile was $67.1 \%, 42.4 \%$, and $50.4 \%$, respectively (33).

The limitations of this study must be mentioned in interpreting the results. First, hip fracture hospitalization rates may be overestimated, as it was not possible to identify patients who were transferred from another study hospital. Second, the number of hip fractures may have been under- or overestimated by misclassification of the disease. Third, the number of cases would be underestimated if patients were treated outside of a hospital, although approximately $85 \%$ to $100 \%$ of all patients with hip fracture are hospitalized (19). In Ecuador, however, the number of patients treated outside of a hospital after a hip fracture is undetermined.

In conclusion, the results of this study indicate a low incidence of hip fractures in Ecuador and geographic differences of hip fracture rates in Latin America. Because the population of Ecuador is aging, this study provides valuable information to public health authorities to start planning and implementing strategies to prevent falls and osteoporosis aimed at reducing the burden of hip fractures in the near future. Further epidemiologic research is needed to examine risk factors that could explain possible differences in hip fracture rates among countries in Latin America.

\section{REFERENCES}

1. Cummings SR, Melton JL. Epidemiology and outcomes of osteoporotic fractures. Lancet. 2002;359:1761-7.

2. Cooper C, Cmapion G, Melton LJ. Hip fractures in the elderly: a world-wide projection. Osteoporos Int. 1992;2:285-9.

3. Dennison E, Maysan A, Cooper C. Epidemiology of osteoporosis. Rheum Dis Clin North Am. 2006;32:617-9.
4. Kasstad TS, Meyer HE, Falch JA. Incidence of hip fracture in Oslo, Norway: differences within city. Bone. 1998;22(2):175-8.

5. Bacon WE, Maggi S, Looker A, Harris T, Nair $\mathrm{CR}$, Giaconi J, et al. International comparison of hip fracture rates in 1988-89. Osteoporos Int. 1996;6:69-75.

6. Latin American and Caribbean Demographic Centre. Demographic bulletin no. 62. Latin
America: population projections $1970-2050$ Santiago, Chile: CELADE; 1988.

7. Clark P, Lavielle P, Franco-Marina F, Ramirez E, Salmeron J, Kanis J, et al. Incidence rates and life time risk of hip fractures in Mexicans over 50 years of age: a population-based study. Osteoporos Int. 2005;16:2025-30.

8. Fatalities and injuries from falls among older adults-United States, 1993-2003 and 2001- 
2005. MMWR Morb Mortal Wkly Rep. 2006; 55(45):1221-4

9. Morales-Torres J, Gutierrez-Urena S. The burden of osteoporosis in Latin America. Osteoporos Int. 2004;15:625-32.

10. Instituto Nacional de Estadística y Censos. Available from: http://www.inec.gov.ec/ proyecciones/proy.html. Accessed September 2007.

11. Climate of Ecuador. Available from: http:// www.languagecrossing.com/Destinations/ Ecuador/Climate_of_Ecuador/. Accessed September 2007.

12. Organización Panamericana de la Salud. Available from: http://www.paho.org/Spanish/ DD/AIS/cp_218.htm. Accessed September 2007.

13. Instituto Nacional de Estadística y Censos. Available from: http://www.inec.gov.ec/ interna.asp?inc $=$ pb_publicacion\&idPub $=10$. Accessed September 2007.

14. World Health Organization. 2007. International statistical classification of diseases and related health problems, 10th revision. Available from: http://www.who.int/ classifications/apps/icd/icd10online/. Accessed September 2007.

15. U.S. Census Bureau. Available from: http:// www.census.gov/. Accessed September 2007.

16. Morosano M, Masoni A, Sanchez A. Incidence of hip fracture in the city of Rosario, Argentina. Osteoporos Int. 2005;16:1339-44.

17. Mosquera M, Maurel D, Pavon S, Arregui A, Moreno C, Vazquez J, et al. Incidencia y factores de riesgo de la fractura de femur proximal por osteoporosis. Rev Panam Salud Publica. 1998;3(4):211-8.
18. Bagur A, Mautalen C, Rubin Z. Epidemiology of hip fractures in an urban population of central Argentina. Osteoporos Int. 1994;4:332-5.

19. Lopes Silveira V, Chagas Medeiros M, Macedo Coelho-Filho J, Mota RS, Noleto JC, Costa FS, et al. Hip fracture incidence in an urban area in Northeast Brazil. Cad Saúde Pública. 2005:21(3):907-12.

20. Castro da Rocha FA, Ribeiro AR. Low incidence of hip fractures in an equatorial area. Osteoporos Int. 2003;14(6):496-9.

21. Fang J, Freeman R, Jeganathan R, Alderman $\mathrm{MH}$. Variations in hip fracture hospitalization rates among different race/ethnicity groups in New York City. Ethn Dis. 2004;14:280-4.

22. Hennekens $\mathrm{CH}$, Buring JE. Measures of disease frequency and association. In: Epidemiology in medicine. Boston/Toronto: Little, Brown and Company; 1987. Pp. 55-98.

23. Abramson JH, Gahlinger PM. Computer programs for epidemiologists. PEPI version 4.0. Salt Lake City, Utah: Sagebrush Press; 2001.

24. Lofman O, Berglund K, Larson L, Toss G. Changes in hip fracture epidemiology: redistribution between ages, genders and fracture types. Osteoporos Int. 2002;13:18-25.

25. Melton LJ III, Therneau TM, Larson DR. Long-term trends in hip fracture prevalence: the influence of hip fracture incidence and survival. Osteoporos Int. 1998;8:68-74.

26. Kanis JA, Oden A, Hohnell O. The components of excess mortality after hip fracture. Bone. 2003;32:468-73.

27. Myers AH, Robinson EG, Natta ML, Michelson JD, Collins K, Baker SP. Hip fracture among the elderly: factors associated with in- hospital mortality. Am J Epidemiol. 1991;134: 1128-37.

28. Benet-Trave J, Dominguez-Garcia A, SalesPerez J. In-hospital case-fatality of aged patients with hip fracture in Catalonia, Spain. Eur J Epidemiol. 1997;13:681-6.

29. Jacobsen SJ, Sargent DJ, Atkinson EJ, O'Fallon WM, Melton LJ. Population-based study of the contribution of weather to hip fracture seasonality. Am J Epidemiol. 1995;141:79-83.

30. Lau EM, Gillespie BG, Valenti L, O'Connell D. The seasonality of hip fracture and its relationship with weather conditions in New South Wales. Aust J Public Health. 1995;19: 76-80.

31. Bischoff-Ferrari H, Orav J, Barrett J, Baron J. Effect of seasonality and weather on fracture risk in individuals 65 years and older. Osteoporos Int. 2007;18:1225-33.

32. Bischoff-Ferrari H, Dawson-Hughes B, Willet WC, Staehelin HB, Bazemore MG, Zee RY, et al. Effect of vitamin D on falls. JAMA. 2004; 291:1999-2006.

33. Lips $P$, Hosking D, Lippuner K, Norquist JM, Wehren L, Maalouf G, et al. The prevalence of vitamin D inadequacy amongst women with osteoporosis: an international epidemiological investigation. J Intern Med. 2006;260: $245-54$.

Manuscript received on 16 March 2008. Revised version accepted for publication on 24 August 2008.
RESUMEN

\section{Epidemiología de las fracturas de cadera en Ecuador}

Palabras clave
Objetivos. Determinar la incidencia de fracturas de cadera por edad, sexo y tipo en Ecuador. Como objetivo secundario se analizaron las variaciones geográficas de las fracturas de cadera en América Latina.

Métodos. Se analizó el Anuario de Egresos Hospitalarios para determinar el número de personas de 50 años o más hospitalizadas con un diagnóstico principal de fractura de cadera (DIE-10 S72) en 2005. Se utilizaron los estimados de población del censo como denominadores para calcular la incidencia de fracturas de cadera por 100000 habitantes. Para analizar las variaciones geográficas de las fracturas de cadera se calcularon las tasas ajustadas por la edad por el método directo, con la población de los Estados Unidos de América en 2000 como estándar.

Resultados. Durante el período de estudio, 1005 personas estuvieron hospitalizadas con diagnóstico principal de fractura de cadera (664 mujeres y 341 hombres). La incidencia anual bruta de fracturas de cadera fue de 49,5 por 100000 habitantes $(34,8$ por 100000 hombres y 63,2 por 100000 mujeres). En general, el número de fracturas de cadera y su incidencia aumentó exponencialmente con la edad en ambos sexos. Sin embargo, el aumento fue mayor en las mujeres. Las tasas ajustadas por la edad en América Latina variaron entre un mínimo de 15,1 por 100000 mujeres y 6,7 por 100000 hombres en Sobral, Brasil, y un máximo de 499,0 por 100000 mujeres en La Plata, Argentina.

Conclusiones. Estos resultados muestran una baja incidencia de fracturas de cadera en Ecuador y diferencias geográficas en las tasas de fracturas de cadera en América Latina. Debido al envejecimiento de la población en Ecuador, esta información es de interés de las autoridades de salud pública para comenzar a elaborar e implementar estrategias de prevención dirigidas a reducir en el futuro cercano la carga que ocasionan las fracturas de cadera.

Fracturas de cadera, osteoporosis, Ecuador. 